\title{
Mycale (Aegogropila) kolletae sp. n. from the SE Atlantic, with comments on the species of Mycale Gray with raphidotoxas (Mycalidae, Demospongiae, Porifera)
}

\author{
José Luis Carballo ${ }^{1}$ \\ Eduardo Hajdu ${ }^{2}$
}

\begin{abstract}
A new species of Mycale Gray, 1867 bearing raphidotoxas is described from the Namibian coast (SE Atlantic). Mycale (Aegogropila) kolletae sp. n. is characterized by having raphidotoxas up to $590 \mu \mathrm{m}$ long, three distinct categories of anisochelae, two categories of sigmas, very small raphides, and most of all, by toxas serrated in an unusual pattern (on the inner parts of all three bends). Mycale magnirhaphidifera Van Soest, 1984 is redescribed from the Brazilian coast, based on a population from the northern São Paulo State coastline. The remaining two species with raphidotoxas, viz. Mycale rhaphidotoxa Hentschel, 1912 and M. mannarensis Thomas, 1968 are revised. LÉvI's (1963) record of Carmia macilenta (Bowerbank, 1866 ) for the South African coast was reevaluated and found conspecific with $M$. kolletae sp. $\mathbf{n}$. It has both raphidotoxas as well as toxas with bends which are serrated on their inner surfaces. An identification key for all the Mycale with raphidotoxas is given, and a discussion on possible phylogenetic interpretations for the occurrence of raphidotoxas is advanced.

KEY WORDS. Poecilosclerida, Mycalidae, Mycale, taxonomy, microscleres, raphidotoxas, subgeneric classification, phylogeny
\end{abstract}

Mycale Gray, 1867 is one of the most diverse sponge genera (DouMENC \& LÉVI 1987; HAJDU 1999), and it is currently one of the most dynamic in discoveries and descriptions of new species (over 15 new species in the last decade), which is suggestive of a considerable adaptative radiation (HAJDU \& DESQUEYROUX-FAÚNDEZ 1994; HAJDU et al. 1995; CARBALLO \& HAJDU 1998; HAJDU \& RÜTZLER 1998). Mycale s great diversity is also reflected in the possession of a large variety of architectures, as well as in the number of categories of some of the spicules. Moreover, the micromorphology of the microscleres is also very diversified (HENTSCHEL 1913; DENDY 1921; DOUMENC \& LÉVI 1987), and has great taxonomic value (HAJdu 1995; HaJdu \& Soest 1996; CARBallo \& Hajdu 1998). This is evident in the widespread use of scanning electronic microscopy in the description of new species (e.g. BUIZER \& SOEST 1977; CARBALlo \& HAJDU 1998). In spite of a varied set of spicule types and skeletal arrangements, former assays have failed to produce an entirely consistent and much needed classification scheme (e.g.

1) Instituto de Ciencias del Mar y Limnología, Universidad Autonoma de Mexico. Estación Mazatlán, Apartado Postal 811, Mazatlán 82000 México.

E-mail: carballo@ola.icmyl.unam.mx

2) Departamento de Invertebrados, Museu Nacional, Universidade do Brasil. Quinta da Boa Vista, 20940-040 Rio de Janeiro, Rio de Janeiro, Brasil. E-mail: hajdu@acd.ufrj.br 
Hajdu \& Desqueyroux-Faúndez 1994; Carballo \& HaJdu 1998; HaJdu \& RÜTZLER 1998; HAJDU 1999). The currently largely accepted scheme is based on the arrangement of the ectosomal skeleton. Proposed by TOPSENT (1924), and amended by later authors (VAN SOEST 1984; BERGQUIST \& FROMONT 1988), it was shown to be plastic at the species level (HAJDU \& RÜTZLER 1998) as well as incongruent with the distribution of micracantoxeas (CARBALLO \& HAJDU 1998).

Another spicule type, with a distribution which is seemingly inconsistent with the ectosomal skeletal arrangement, has been variously termed raphidotoxa (HENTSCHEL 1912) and magnirhaphide (VAN SOEST 1984). These are very long (usually over $200 \mu \mathrm{m}$ ) and very thin (usually less than 1-2 $\mu \mathrm{m}$ ) microscleres, generally slightly sinuous or gently bent, hence the indecision for calling it a raphid or a toxa. However, we prefer to use the name proposed by HENTSCHEL (1912) because of its precedence over VAN SOEST's (1984), and therefore will be calling these spicules raphidotoxas.

A new species with raphidotoxas, collected off the Namibian coast and a population of M. magnirhaphidifera Van Soest, 1984 from the northern São Paulo State coastline (Brazil) are described; and the remaining two species with raphidotoxas, viz. Mycale rhaphidotoxa Hentschel, 1912 and M. mannarensis Thomas, 1968 are briefly revised. A discussion on possible phylogenetic interpretations for the possession of raphidotoxas is advanced.

\section{MATERIAL AND METHODS}

Specimens were collected by scuba diving and preserved in $96 \%$ ethanol. The preparation of dissociated spicules, both for light and scanning electron microscopy (SEM), as well as thick sections, followed the techniques described in RÜTZLER (1978). African specimens were studied in a Philips XL 20 SEM under accelerating (AV) voltages between 25 and $30 \mathrm{Kv}$, working magnifications (M) up to $9013 \mathrm{X}$. Brazilian specimens were studied partly on a Jeol JSM 35-L machine (AV $25 \mathrm{KV}$, WD $15 \mathrm{~mm}, \mathrm{M}$ 3600x) of the Institute for Biodiversity and Ecosystem Dynamics (University of Amsterdam); and partly on a Zeiss DSM-940 machine (AV 17-19 KV, WD ca. $8 \mathrm{~mm}, \mathrm{M}$ up to $10000 \mathrm{x}$ ) of the Instituto de Biociências (University of São Paulo).

Abbreviations used are LBM (Laboratorio de Biología Marina, Universidad de Sevilla, Spain), MCNM (Museo de Ciencias Naturales de Madrid), MNRJ (Museu Nacional, Universidade do Brasil), SMF (Senckenberg Museum, Frankfurt)

\section{Mycale (Aegogropila) kolletae sp. $\mathbf{n}$.}

Figs 1-19, Tab. I

Carmia macilenta; Lévi 1963: (non Hymeniacidon macilenta Bowerbank, 1866).

Material studied. Holotype MCNM-1/01/175 (Madrid-Spain), Penguin Island, Namibia, $8-12 \mathrm{~m}$ depth, water temperature $10^{\circ} \mathrm{C}$, J.L. Carballo $l e g$. Paratypes: LBM-28/1 1/95-1/042 (Sevilla, Spain), Possession Island, 2700'45 S-15¹1'76 W Namibia, 5-7 $\mathrm{m}$ depth, water temperature $9^{\circ} \mathrm{C}$, J.L. Carballo leg. Additional material: LAM 44D, Carmia macilenta sensu LÉVI (1963). Comparative material: Hymeniacidon macilenta Bowerbank, 1866 - Holotype, BMNH 1910.1.1.134-135. 


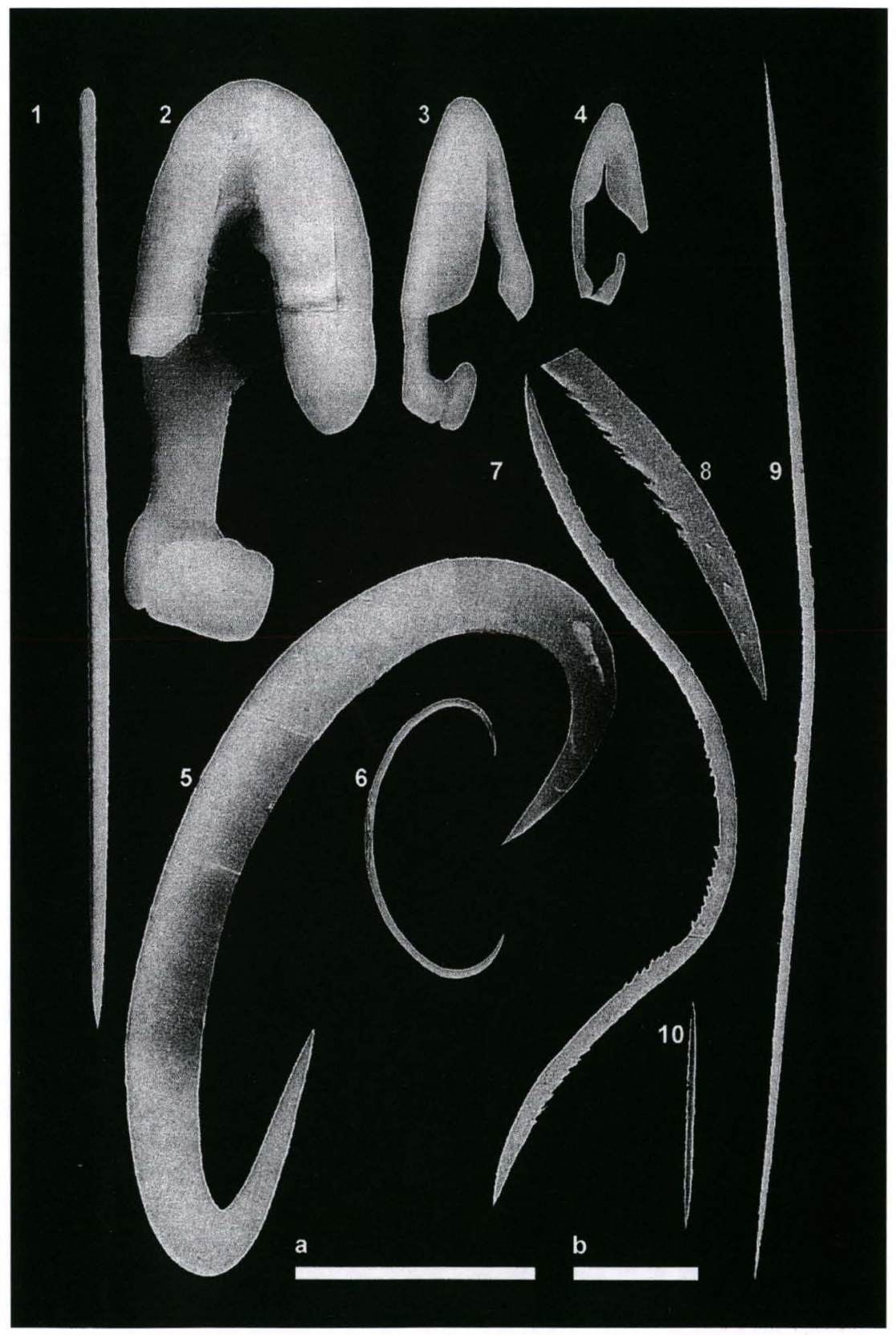

Figs 1-10. SEM micrographies of spicules of Mycale kolletae sp. n. (Holotype). (1) Mycalostyle; (2) Anisochela-I; (3) Anisochela-II; (4) Anisochela-III; (5) Sigma-I; (6) Sigma-II; (7) serrated toxa; (8) detail of serrated toxa, rhaphide; (9) raphidotoxa; $(10)$ raphide. Scales: $a=100 \mu \mathrm{m}(1$, $9), b=10 \mu \mathrm{m}(2-7,10)$ and $5 \mu \mathrm{m}(8)$. 
Diagnosis. Mycale (Aegogropila) with raphidotoxas, anisochelae-I, -II, -III, two morphologically distinct size classes of sigmas, characteristically bow-shaped toxas serrated on all three bends, and very small raphides.

Description. Encrusting to cushion-shaped up to $1-1.9 \mathrm{~cm}$ thick, extent of spread approximately $11 \times 7 \mathrm{~cm}^{2}$. The consistency is soft and slightly compressible. The surface is irregular. Oscules of approximately $1-2 \mathrm{~mm}$ in diameter. We did not observe subectosomal canals, but subectosomal spaces are conspicuous. Ectosome supported by specialized skeleton. Colour in life light yellow. Growing on rocks and between Laminaria sp. roots.

Skeleton: The ectosomal skeleton varies from tangential loose spicules to a confused network detachable only in parts. The choanosomal skeleton is made of wavy, ascending tracts of mycalostyles, branching towards the ectosome from the base of the sponge. The tracts of mycalostyles have a reticulated/plumoreticulated architecture. In the flesh between the tracts the microscleres are strewn at random without any special arrangement. Anisochelae in rosettes were not observed.

Spicules (Figs 1-10, 11-19, Tab. I): Megascleres are usually straight mycalostyles with hardly perceptible tyle, generally slightly bent at mid length. Microscleres: anisochelas I are stout, with head length almost $60 \%$ of total length, frontal alae of foot with a slight central prominence on top. Anisochelas II of a different morphology than the previous one, with head length almost $70 \%$ of total length, with nearly straight shaft. Anisochelas III slender, lateral alae of the head commonly fused with frontal one, frontal alae of foot with short, digitiform processes on top. Typically, the frontal alae of the head are longer than the lateral alae. Sigmas I, robust, C-shaped contorted, abruptly bent into hooks with sharp endings. Sigmas II very slender (stout in LAM 44D), C-shaped contorted. Raphidotoxas thin and large, gently curved. Toxas bowshaped, serrated on the inner parts of all three bends. Raphides straight, sharply pointed, fusiform (microxea-like), seen singly or in very small bundles.

Distribution and ecology. South Africa (LÉVI 1963), Namibia. On rocks, between Laminaria sp. roots, etc.

Etymology. The name is after Miss Kollet Glober, of Sea Fisheries Research of the Ministry of Fisheries and Marine Resources of the Republic of Namibia for her help during the sampling.

Remarks. Mycale kolletae sp. $\mathbf{n}$. differs from the other known species with raphidotoxas by the possession of three categories of anisochelae and two categories of sigmas. Moreover, to our knowledge, this is the first report of serrated toxas for the genus. Terminally microspined toxas are relatively common in the Microcionidae (Microcionina, Poecilosclerida; e.g. HoOPER 1996), but these are morphologically distinct and most likely not homologous. This is a unique occurrence which widens the already large morphospace exhibited by species of Mycale (HAJDU 1995). Mycale kolletae sp. n. possesses an ectosomal skeletal arrangement which is not the typical neat reticulation of megasclere bundles of Aegogropila, rather, it has a major component of single spicules, where paucispicular tracts are only seldom seen. We consider nevertheless that the reticulated pattern is visible, if not clearly so, and assign $M$. kolletae sp. n. to the subgenus Aegogropila. The pattern observed in Mycale (Mycale) is much more spicule dense than that observed here. 
LÉVI's (1963) record of Carmia macilenta (Bowerbank, 1866; = M. macilenta) has been reexamined (Figs 11-19) and found conspecific to M. kolletae sp. n. The holotype of $M$. macilenta has been reexamined too, and found to be distinct from the new species described here in several aspects. It has 1) megascleres which are much thinner; 2) anisochelae-I much skinnier; 3) toxas which can be much larger, and which are never acanthose; and 4) absence of any raphides.

Table I. Comparative data for the dimensions of the spicules (in $\mu \mathrm{m}$ ), ectosomal architecture and geographic distribution of the Mycale species with raphidotoxas

\begin{tabular}{|c|c|c|c|c|c|}
\hline & M. rhaphidotoxa & M. mannarensis & M. magnirhaphidifera ${ }^{1}$ & M. magnirhaphidifera ${ }^{2}$ & M. kolletae sp. $\mathrm{n}^{3}$ \\
\hline Mycalostyles & $304-392 \times 5-6$ & $294-315 \times 4-8$ & $236-270 \times 1.5-3$ & $196-286 \times 4.4$ & $\begin{array}{c}250-372 \times 9.5-16.5 \\
(250-360 \times 6-12)\end{array}$ \\
\hline Anisochelas & $\begin{array}{c}\text { I: } 39-45 \text { in rosettes } \\
\text { II: } 17-20\end{array}$ & I: $21-42$ & $\begin{array}{l}\text { I: } 31-35 \text { in rosettes } \\
\text { II: } 11-13\end{array}$ & $\begin{array}{c}\text { I: } 31-35 \text { in rosettes } \\
\text { II: } 11-13\end{array}$ & $\begin{array}{c}\text { I: } 35-43.5(30-48) \\
\text { II: } 20.5-26(20-28.4) \\
\text { III:13.5-17 } \\
(10-15.9)\end{array}$ \\
\hline Sigmas & $63-96$ & $63(75) 84 \times 1(3.1) 4$ & not found & $\begin{array}{l}\text { I: } 32(43.6) 50 \\
\text { II: } 13-21\end{array}$ & $\begin{array}{l}\text { I: } 35-82.5 \times 2.2-3 \\
(70-105.5 \times 4-7) \\
\text { II: } 19-23.5(14-39)\end{array}$ \\
\hline Toxas & - & - & - & - & $45-60$ (serrated) \\
\hline Raphidotoxas & $\begin{array}{l}200-300 \text { (in } \\
\text { bundles) }\end{array}$ & $376-528$ & $260-310$ (in dragmas) & $\begin{array}{l}\text { I: } 90-241 \\
\text { II: } 13-22\end{array}$ & $380-590$ \\
\hline Rhaphides & - & - & - & - & $6-11(5-10)$ \\
\hline $\begin{array}{l}\text { Ectosomal } \\
\text { architecture }\end{array}$ & Carmia & Aegagropila & Carmia & Carmia & Aegragopila \\
\hline Distribution & $\begin{array}{c}\text { Indian Ocean } \\
\text { (Moluccas), over } \\
\text { coral, } 12 \mathrm{~m} \text { depth }\end{array}$ & $\begin{array}{l}\text { Indian Ocean on } \\
\text { Halimeda sp, } 1 \mathrm{~m} \\
\text { depth }\end{array}$ & $\begin{array}{c}\text { Caribbean (Curaçao), } \\
\text { on worm tubes }\end{array}$ & $\begin{array}{l}\text { Caribbean (Belize), on } \\
\text { mangroove roots }\end{array}$ & $\begin{array}{l}\text { South east } \\
\text { Atlantic, on } \\
\text { Laminaria roots, } \\
\text { over rocks }\end{array}$ \\
\hline
\end{tabular}

(1) VAn Soest 1984; (2) Hajdu \& RützleR 1998; (3) data for the paratype is shown between brackets.

\section{Mycale (Aegogropila) mannarensis Thomas, 1968}

Tab. I

Diagnosis. Mycale (Aegogropila) with raphidotoxas mostly over $400 \mu \mathrm{m}$ long, with anisochelae and sigmas not separable into different categories, no toxas.

Brief description (adapted from THOMAS 1968: 255). Encrusting sponge (maximum thickness of $2 \mathrm{~mm}$ ), rather fleshy and slimy to touch. The colour in life is black. Surface smooth and slimy. Ectosome not detachable, with a well developed reticulation of bundles of mycalostyles, and between them, tracts of raphidotoxas can appear arranged in long and continuous bands. Main skeleton consists of ill-defined fibers arranged at a slanting angle to the surface. Mycalostyles with straight shaft, and head prominent in some. Anisochelae in rosettes, not separable into different categories. Sigmas, flat or contorted. Raphidotoxas slender and straight, middle portion widest. 


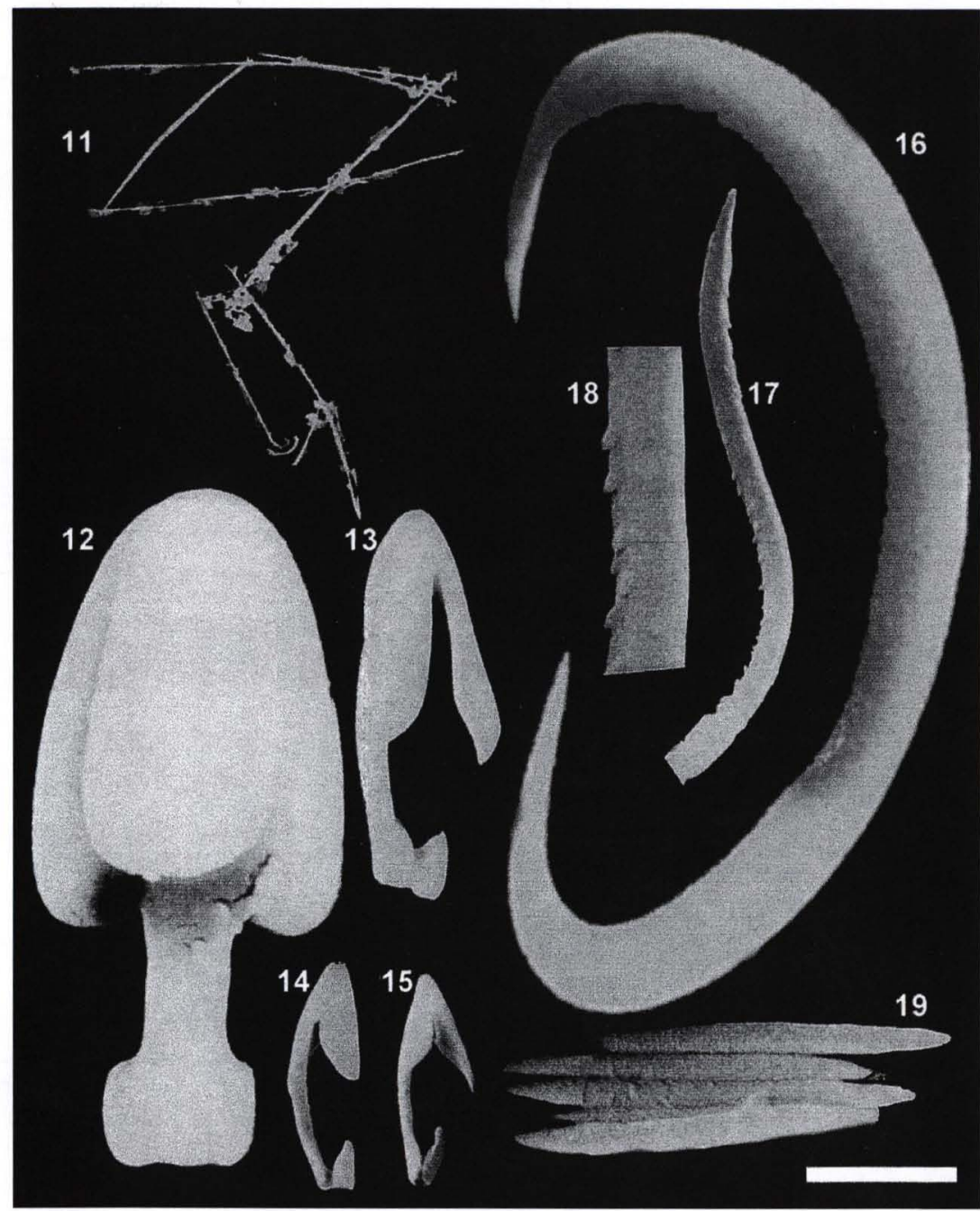

Figs 11-19. SEM micrographies of the spicules of Mycale kolletae sp. $\mathbf{n}$. (Paratype, $=$ Carmia macilenta sensu LÉVI 1963). (11) Raphidotoxas; (12) Anisochela-l; (13) Anisochela-II; (14) Anisochela-III (oblique view); (15) Anisochela-III (side view); (16) Sigma-I; (17) serrated toxa (in part); (18) detail of serrated toxa; (19) raphides in a bundle. Scales: $a=200 \mu \mathrm{m}(11), 10 \mu \mathrm{m}$ (12-17), $5 \mu \mathrm{m}$ (18), $3 \mu \mathrm{m}(19)$.

Distribution and ecology. So far known from its type locality only, viz. Hare Island (Gulf of Mannar, India). Common on Halimeda sp. (calcareous algae) beds, at $1 \mathrm{~m}$ depth.

Remarks. It has not been possible to obtain the type of $M$. (A.) mannarensis on loan, but the raphidotoxas with a mean length around $400 \mu \mathrm{m}$ together with the absence of toxas, as recorded by THOMAS (1968), make this species clearly recognizable from other Mycale with raphidotoxas. 


\section{Mycale (Carmia) magnirhaphidifera Van Soest, 1984}

Figs $20-29$, Tabs $1-2$

Refer to HAJDU \& RÜTZLER (1998) for a synonymy list.

Material studied. BraziL, São Paulo, Ilha de São Sebastião, Ilhabela:

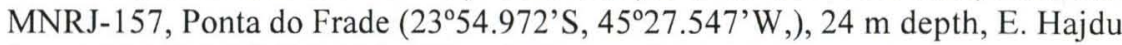
leg., 16.I.1996; MNRJ-196, 197 and 227, small inlet between Ponta da Sela and Ponta da Figueira $\left(23^{\circ} 53.127^{\prime}\right.$ S, $45^{\circ} 27.526^{\prime}$ W), $12 \mathrm{~m}$ depth, E. Hajdu leg., 16.I. 1996; MNRJ-345, submerged islet (stone slab) on the west of Ilha da Serraria ( $23^{\circ} 48.758^{\prime}$ S, $\left.45^{\circ} 13.812^{\prime} \mathrm{W}\right), 5-21 \mathrm{~m}$ depth, E. Hajdu \& G. Muricy leg., 25.I. 1996; MNRJ 530, Ponta do Frade (2354.972'S, $\left.45^{\circ} 27.547^{\prime} \mathrm{W}\right), 5-8 \mathrm{~m}$ depth, E. Hajdu leg., 21.VI.1997; MNRJ 532, small inlet between Veloso and São Pedro

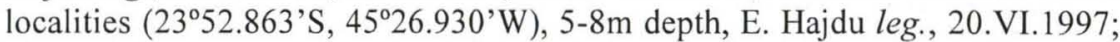
MNRJ 562, Ilhota da Prainha ( $23^{\circ} 51.146$ 'S , 4524.997'W), 4 m depth, E. Hajdu

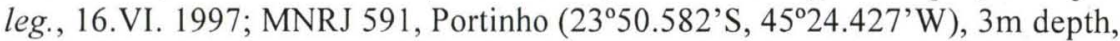
E. Hajdu leg., 19.VI.1997; MNRJ-777 and 780, submerged islet (stone slab) on the west of Ilha da Serraria $\left(23^{\circ} 48.758^{\prime} \mathrm{S}, 45^{\circ} 13.812^{\prime} \mathrm{W}\right), 20 \mathrm{~m}$ depth, E. Hajdu leg., 11.I.1996; MNRJ 1330, Praia Preta (23⒋ $\left.4.247^{\prime} \mathrm{S}, 45^{\circ} 24.435^{\prime} \mathrm{W}\right), 1-2 \mathrm{~m}$ depth, E. Hajdu, E. Costa \& R. Fernandes leg., 22.XII.1997; MNRJ 1334, Saco do Sombrio ( $23^{\circ} 53.850^{\prime} \mathrm{S}, 45^{\circ} 14.900^{\prime} \mathrm{W}$, southern Castelhanos Bay), 2-3 m depth, E. Hajdu leg., 03.XII.1997; MNRJ 1653, northern Ilha das Cabras (23 49.715'S, 45²3.569'W), 3.5 m depth, E. Hajdu leg., 16.IV.1998; MNRJ 1998,

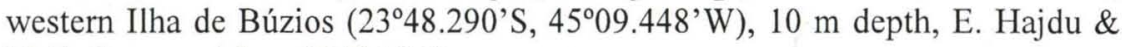
M.C. Guerrazzi leg., 07.II.1999.

Diagnosis. Encrusting, deep-purple to brown-grey Mycale (Carmia) with anisochelae-I always smaller than $40 \mu \mathrm{m}$ long, and anisochelae-II always smaller than $15 \mu \mathrm{m}$ long, with or without sigmas smaller than $50 \mu \mathrm{m}$ long; and two size classes of raphides, the larger ones, raphidotoxas over $200 \mu \mathrm{m}$ in length, and the smaller ones mostly under $20 \mu \mathrm{m}$.

Description. The species is always thinly encrusting, less than $2 \mathrm{~mm}$ thick. Specimens often cover over $100 \mathrm{~cm}^{2}$, and in some cases were observed to spread over $300 \mathrm{~cm}^{2}$. They are fragile (very soft), and possess a smooth surface where irregularities are due to the underlying substrate (e.g. barnacles, limpets, bivalves, coraline algae). Colour alive is most frequently a deep-purple. Oscula are few, spread over the sponge surface, and often small $(<5 \mathrm{~mm}$ in diameter). Subectosomal canals are frequently conspicuous, sometimes marked by a whitish tinge, and converge in a starry pattern to the oscula.

Skeleton. The ectosomal skeleton consists in some specimens, of a dense feltwork of large raphidotoxas (ca. $100 \times 400 \mu \mathrm{m}$ ), where rosettes of anisochelae-I (10-15 spicules, ca. $100 \mu \mathrm{m}$ in diameter) are common too. The choanosomal skeleton is made of sinuous ascending tracts of megascleres, which diverge slightly into brushes when approaching the surface. Anisochelae-II and -III may be very common all over the sponge.

Spicules. (Figs 20-29, Tab. I-II) Megascleres are mycalostyles, smooth, straight or nearly so, slender, with abrupt sharpening of the apex, and well-marked 


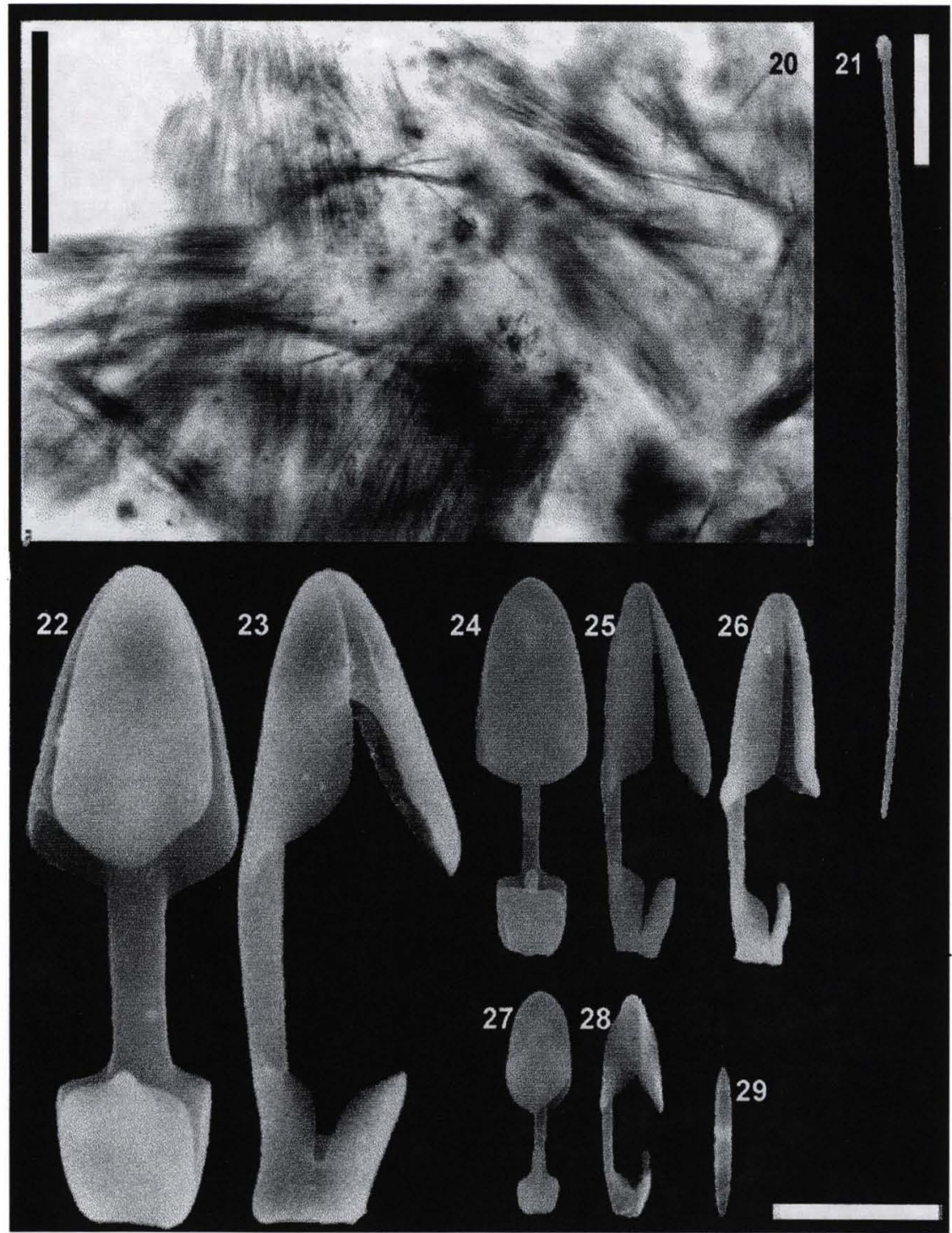

Figs 20-29. Ectosomal skeleton and SEM micrographies of the spicules of Brazilian Mycale magnirhaphidifera Van Soest, 1984. (20) Ectosomal architecture with conspicuous large trichodragmas of raphidotoxas. Rosettes of anisochelae-I are visible near the centre of the image; (21) Mycalostyle; (22) Anisochela-I, face view; (23) Anisochela-I, side view; (24) Anisochelae-II, face view; (25) Anisochela-II, side view; (26) Anisochela-II, side view; (27) Anisochela-III, face view; (28) Anisochela-III, side view; (29) Raphide. Scales $=100 \mu \mathrm{m}(20)$, $50 \mu \mathrm{m}$ (21), 10 $\mu \mathrm{m}$ (22-29). 
elliptic heads. Microscleres: Anisochelae-I, slender, very slightly curved on profile view, head about $50 \%$ of total spicule length, both frontal alae nearly straight, faint digitiform process on top of the frontal alae of the foot. Anisochelae-II, nearly straight on profile view, head about $55 \%$ of total spicule length, base of frontal alae of the head may be slightly bent forward, base of lateral alae of the head may be slightly bent backward protruding over the shaft, digitiform process on top of the frontal alae of the foot may be present. Anisochelae-III, slender, slightly curved on profile view, head about $50 \%$ of total spicule length, head slightly constricted distally, marked digitiform process on top of the frontal alae of the foot (nearly doubling the length of the foot). Raphidotoxas, very thin, straight, slightly bent or slightly sinuous, sharply pointed. Raphides, short, stout, fusiform (microxea-like), sharply pointed.

Distribution and ecology. The species is widespread in the Tropical western Atlantic, with a single dubious report from Subtropical NW Atlantic waters. In the SW Atlantic (São Sebastião Channel and its environs) it is a common species, usually confined to semi-obscure environments. It will occur outside small caves, but on vertical rocky walls. Its known depth range is from ca. 1 to $24 \mathrm{~m}$. A specimen bearing larvae was seen in 16.VI.1998. MNRJ 1334 was associated to a living scallop, and was thus a "mobile sponge".

Remarks. The presence of sigmas seems to be a variable trait among different populations of this species, which conform on many other details of sponge habitus and spicule morphology. Micrometric data reported here match well with data for Caribbean specimens (VAN SOEST 1984; HAJDU \& RÜTZLER 1998; Tab. II).

Table II. Comparative data for the dimensions of the spicules (in $\mu \mathrm{m}$ ) of selected Brazilian specimens of Mycale (Carmia) magnirhaphidifera Van Soest, 1984. Values between brackets are means. Micrometries for the megascleres are shown as length/head width/shaft width.

\begin{tabular}{|c|c|c|c|c|}
\hline Specimens & Mycalostyles & Anisochelae & Raphidotoxas & Raphides \\
\hline \multirow[t]{3}{*}{ MNRJ 196} & $270(287.5) 300$ & I: $35(38.2) 42$ & $243(257.0) 310$ & \\
\hline & $13.7(5.6) 8.8$ & II: $22(23.0) 24$ & & \\
\hline & $12.5(4.6) 7.5$ & III: $12(14.0) 16$ & & \\
\hline \multirow[t]{3}{*}{ MNRJ 197} & $184(277.9) 320$ & I: $38(39.5) 42$ & $281(322.0) 359$ & \\
\hline & $12(2.5) 3$ & II: $20(22.9) 25$ & & \\
\hline & $/ 1(2.1) 3$ & III: $11(13.6) 16$ & & \\
\hline \multirow[t]{3}{*}{ MNRJ 227} & $243(255.3) 272$ & I: $34(38.2) 46$ & $272(309.9) 340$ & $7.2(N=1)$ \\
\hline & $11.5(2.5) 3$ & II: $20(22.8) 24$ & & \\
\hline & $11.5(2.0) 3$ & III: $13(14.5) 16$ & & \\
\hline \multirow[t]{3}{*}{ MNRJ 345} & $262(277.9) 301$ & I: $31(34.1) 36$ & $180(237.5) 280$ & \\
\hline & $11.5(2.4) 3$ & II: $19(20.8) 23$ & & \\
\hline & $11(2.1) 3$ & III: $11(12.4) 14$ & & \\
\hline \multirow[t]{3}{*}{ MNRJ 777} & $233(257.5) 301$ & I: $28(31.0) 37$ & $272(304.6) 330$ & \\
\hline & $15(6.3) 7.5$ & II: $19(22.0) 24$ & & \\
\hline & $13.8(5.1) 7.5$ & III: $12(13.3) 14$ & & \\
\hline \multirow[t]{3}{*}{ MNRJ 780} & $224(269.2) 310$ & I: $29(32.4) 36$ & $213(266.7) 310$ & \\
\hline & $15(6.9) 8.8$ & II: $19(21.6) 26$ & & \\
\hline & $13.8(5.8) 7.5$ & III: $11(13.1) 16$ & & \\
\hline
\end{tabular}




\section{Mycale (Carmia) rhaphidotoxa Hentschel, 1912}

Tab. I

Material studied. Holotype SMF 1034, Strait of Dobo (stn. 15), Aru Islands, Indonesia, 12.III.1908.

Diagnosis. Mycale (Carmia) sp. with raphidotoxas mostly smaller than 400 $\mu \mathrm{m}$, encrusting, yellowish-brown, with anisochelae-I mostly over $40 \mu \mathrm{m}$ long, anisochelae-II over $15 \mu \mathrm{m}$ long, and abundant sigmas over $60 \mu \mathrm{m}$ long.

Brief description (adapted from HENTSCHEL 1912: 340). Thinly encrusting, $9.5 \mathrm{~cm}$ long by $1 \mathrm{~mm}$ thick. Surface finely granulated. Live colour same as in fixative, yellowish-brown. Plumose architecture with ascending spicule tracts ca. $40 \mu \mathrm{m}$ wide and bearing no visible spongin. Ascending tracts diverge in 3 to 7 smaller tracts when approaching the surface. A surface membrane hangs on the terminations of these fibres. Many embryos, ca. $400 \mu \mathrm{m}$ wide, occur in the choanosome. Megascleres are mycalostyles, straight, base only slightly inflated, abruptly pointed, 304$392 / 5-6 \mu \mathrm{m}$ (length/width). Microscleres are anisochelae I in rosettes, slightly curved shaft, head nearly $50 \%$ the total microsclere length, $39-45 \mu \mathrm{m}$. Anisochelae II scattered around, elongated and slender, shaft nearly straight, head $50-66 \%$ of the total microsclere length, 17-20 $\mu \mathrm{m}$. Sigmas (63-96 $\mu \mathrm{m}$ long) and raphidotoxas, mostly in bundles, occur more frequently near the surface. Raphidotoxas often bent at the center, and sometimes in the opposite direction near each end, $200-400 \mu \mathrm{m}$.

Distribution and ecology. The only published record of the species was from its type locality in the Arafura Sea (Dobo Strait, Aru, Indonesia), at $12 \mathrm{~m}$ depth, on coral rocks.

Remarks. The holotype of $M$. (C.) rhaphidotoxa has been reexamined and data as provided by HENTSCHEL (1912) in the original description, found to be correct. The species is clearly set apart from other Mycale with raphidotoxas by its Carmia type of ectosomal skeletal arrangement, and common and conspicuous sigmas always larger than $60 \mu \mathrm{m}$.

\section{Identification key for the species of Mycale with raphidotoxas}

1. Ectossomal skeleton reticulated (Aegogropila type) ............. 2

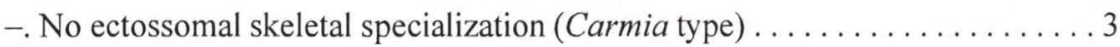

2. Toxas present (serrated) ..................... (A.) kolletae sp. $\mathbf{n}$.

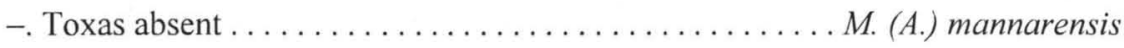

3. Sigmas always larger than $60 \mu \mathrm{m} \ldots \ldots \ldots \ldots \ldots \ldots . . \ldots$. (C.) rhaphidotoxa -. Sigmas, when present, mostly smaller than $50 \mu \mathrm{m}$....M. (C.) magnirhaphidifera

\section{DISCUSSION}

Species of Mycale with raphidotoxas, like those species possessing micracantoxeas (CARBAllo \& HAJDU 1998), also exhibit more than one type of ectosomal architecture. Given the current classification, those sponges are to be spread over more than one subgenus, viz. Aegogropila and Carmia. The alterna- 
tive interpretation for the apparently very restricted occurrence of micracantoxeas, i.e. that they might have been frequently overlooked due to their minute dimensions, is not plausible in regard to raphidotoxas as these are very conspicuous. The remaining possible interpretations focus on the phylogeny of the characters, which may have had either a single or multiple origins. Two possible evolutionary scenarios can be thought of given a single origin of large raphides within Mycale. 1) Species may form a monophyletic group, and their spreading over two distinct subgenera may be entirely artificial; or 2) raphidotoxas may have had an earlier origin with many subsequent losses and reappearances (a switch-on, switch-off model), in which case the splitting of extant species with these microscleres in distinct subgenera need not be artificial. Origin of the character might have been prior to the subgenera in question. Another two possible interpretations can be envisaged given the character's multiple origin. 3) Raphidotoxas may have had a single independent origin within each subgenus, in which case species of Aegogropila bearing the character would most likely constitute a cluster of closely allied species, the same applying to the species of Carmia with raphidotoxas. Two monophyletic clusters of species would exist then. 4) Raphidotoxas may have had several independent origins instead, in which case no Mycale species with these microscleres need be closely allied to any other species with similar spicules, as these are only analogous.

Multiple origin scenarios could be further split into those followed by losses and those where no losses occurred, which only points to how inconclusive this line of reasoning can eventually be.

A quick scrutiny of the character's distribution over a more inclusive universe favours interpretation 2 (the swith-on, switch-of model). It is based on the observation that the raphidotoxas co-occur with the very small, fusiform, microxea-like raphides in Mycale kolletae sp. $\mathbf{n}$. and M. magniraphidifera, the two better known species considered here. The possibility cannot be discarded that such fusiform raphides may be found in the other two species upon closer scrutiny. These smaller raphides were reported recently from Mycale (Mycale) laevis (Carter, 1882), where they occur in dense bundles (trichodragmata; HAJDU \& RÜTZLER 1998). Nevertheless, other species bearing more closely on the issue of the phylogenetic significance of the raphidotoxas, viz. belonging to subgenera Aegogropila, Carmia or Naviculina, have been described recently based on SEM analysis, but no comparable small fusiform raphides were found (e.g. BUIZER \& SOEST 1977; REISWIG \& KAISER 1989; CARBALLO \& GARCIA-GOMES 1994; CARBAllo \& HAJdu 1998; HAJdU \& RÜTZler 1998; HAJdU 1999). It is possible then that a single switch-on event gave rise to the small fusiform, microxea-like raphides considered here, which is congruent with the distribution of the raphidotoxas, but not with the ectosomal architecture, and, perhaps neither with the shape of the anisochelae-I which varies considerably in stoutness.

Raphides of varied lengths are also widespread outside Mycale, both within and outside the Mycalina. Their intermittent occurrence at these levels corroborates the "switch-on, switch-off" mechanism of character expression advocated above (THROCKMORTON 1965; SLUYs 1989; HAJdu et al. 1994). These 
characters can be interpreted as synapomorphies at more exclusive levels of universality, and as "underlying synapomorphies" at more inclusive ones. For a criticism of the concept of "underlying synapomorphies" see FARRIS \& PLATNICK (1989), NELSON (1994) and HAJDU (1995).

ACKNOWLEDGEMENTS. JLC wishes to thank the Ministry of Fisheries and Marine Resources of the Republic of Namibia for the facilities provided, as well as Miss B. Curry and K. Grobler from the Fisheries Centre of the Republic of Namibia for their help in the scientific expedition where the specimens of $M$. kolletae were collected. EH is thankful to R.W.M. van Soest and D. Platvoet (Institute for Biodiversity and Ecosystem Dynamics, University of Amsterdam) for the provision of SEM (JEOL JSM-35) facilities and technical help in SEM operation, respectively; and to A. Ribeiro and E. Mattos (Instituto de Biociencias, Universidade de São Paulo) for the provision of SEM (ZEISS DSM-940) facilities and technical help in SEM operation, respectively. CNPq, FAPERJ, FAPESP and FUJB (all from Brazil) provided financial support in the form of grants and/or fellowships, which is deeply acknowledged.

\section{REFERENCES}

Bergquist, P.R. \& P.J. Fromont. 1988. The marine fauna of New Zealand: Porifera, Demospongiae, Part 4 (Poecilosclerida). N.Z. Oceanog. Inst. Mem. 96: 1-197.

Buizer, D.A.G. \& R.W.M. VAN Soest. 1977. Mycale micracanthoxea nov. spec. (Porifera, Poecilosclerida) from The Netherlands. Neth. Jour. Sea Res. 11 (3/4): 297-304.

CARballo, J.L. \& E. Hajdu. 1998. Micromorphology in Mycale taxonomy (Mycalidae, Poecilosclerida, Demospongiae), with the description of two new micracanthoxea-bearing species. Contr. Zool., Amsterdam, 67 (3): 187-195.

Carballo, J.L. \& J.C. García Gómez. 1994. The Northeastern Atlantic species Mycale micracanthoxea Buizer \& Van Soest, 1977 (Porifera, Poecilosclerida) in the Strait of Gibraltar (southern Spain). Beaufortia 44 (2): 11-16.

DENDY, A. 1921. The tetraxonid sponge spicule: a study in evolution. Acta Zool. 5 (2): 95-152.

DoumEnc, D. \& C. LÉvi. 1987. Anisochelae analysis and taxonomy of the genus Mycale Gray (Demospongiae), p. 73-92. In: J. Vacelet \& N. Boury-Esnault (Eds). Taxonomy of Porifera from the northeast Atlantic and Mediterranean Sea. Berlin, Springer-Verlag, 333p.

FARRIS, J.S. \& N.I PLATNICK. 1989. Lord of the flies: the systematist as a study animal. Cladistics 5: 295-310.

HAJDU, E. 1995. Macroevolutionary patterns within the demosponge Order Poecilosclerida. Phylogeny of the marine cosmopolitan genus Mycale, and an integrated approach to biogeography of the seas. Amsterdam, Univ. Amsterdam, 173p.

. 1999. Toward a phylogenetic classification of Mycalids with anisochelae (Demospongiae: Poecilosclerida), and comments on the status of Naviculina Gray, 1867. Mem. Queens. Museum 44: 225-238.

Hajdu, E. \& K. Rützler. 1998. Sponges, genus Mycale (Poecilosclerida: Demospongiae: Porifera), from a Caribbean mangrove and comments on subgeneric classification. Proc. Biol. Soc. Wash. 111: 737-773.

Hajdu, E. \& R. Desqueyroux-Faúndez. 1994. A synopsis of South American Mycale (Mycale) (Poecilosclerida, Demospongiae), with the description of three new species and a preliminary cladistic analysis of Mycalidae. Rev. Suisse Zool. 101: 563-600.

HAJdu, E. \& R.W.M. van SOEST. 1996. Choosing among Poriferan morphological characters within the cladistic paradigm. Bull. Inst. R. Sci. nat. Belgique, Biol. 66 (Suppl.): 81-88. 
HAJdu, E.; R.W.M. van SOEST \& J.N.A. Hooper. 1994. Proposal of a phylogenetic subordinal classification of poecilosclerid sponges, p. 125-139. In: R.W.M. van SOEST; T.M.G. VAN KEMPEN \& J.C. Braekman (Eds). Sponges in Time and Space. Balkema, Rotterdam, XVIII+515p.

Hajdu, E.; S. Zea; M. Kielman \& S. Peixinho. 1995. Mycale escarlatei $\mathrm{n}$. sp. and Mycale unguifera $\mathrm{n}$. sp. (Mycalidae, Poecilosclerida, Demospongiae) from the tropical western Atlantic. Beaufortia 45 : $1-16$.

HentSCHel, E. 1912. Kiesel- und Hornschwämme der Aru und Kei-Inseln. Ảbhandl. senckenb. naturf. Ges. 34 (3): 293-448.

\section{3. Über einen Fall von Orthogenese bei den Spongien. Zool. Anz. 42: 255-267.}

Hooper, J.N.A. 1996. Revision of Microcionidae (Porifera: Poecilosclerida: Demospongiae), with the description of australian species. Mem. Queens. Mus. 40: 1-626.

LÉvi, C. 1963. Spongiaires d'Afrique du sud. I. Poecilosclerides. Trans. R. Soc. S. Afr. 37 (1): 1-72.

Nelson, G. 1994. Homology: and Sistematics, p. 101-149. In: B.K. HAll (Ed.). Homology: The hierarchical basis of Comparative Biology. San Diego, Academic Press, 483p.

ReISWIG, H.M. \& H. KaISER. 1989. Description of Mycale bamfieldense n. sp. (Porifera, Demospongiae. Poecilosclerida) from Vancouver Island, British Columbia. Can. Jour. Zool. 67: 674-677.

RÜTZLER, K. 1978. Sponges in coral reefs, p. 299-313. In: D.R. STOdDART \& R.E. Johannes (Ed.). Coral reefs: research methods. Monographs on oceanographic methodology 5. Paris, Unesco, 581p.

SLuYs, R. 1989. Rampant parallelism: an appraisal of the use of nonuniversal derived character states in phylogenetic reconstruction. Syst. Zool. 38: 350-370.

SOEST, R.W.M. van. 1984. Marine sponges from Curaçao and other Caribbean localities. Part 3. Poecilosclerida. Stud. Fauna Curaçao Caribbean Islands 66 (199): 1-167.

ThomAs, P.A. 1968. Studies on indian sponges III. Two species of silicious sponges of the family Ophlitaspongiidae de Laubenfels (Class: Demospongiae Sollas, Order: Poecilosclerida Topsent). Jour. Mar. Biol. Ass. India 10 (2): 255-259.

Throckmorton, L.H. 1965. Similarity versus relationship in Drosophila. Syst Zool. 14: 221-236.

TOPSENT, E. 1924. Révision des Mycale de l'Europe occidentale. Ann. Inst. océanogr., Monaco, 1 (3): 77-118. 